\title{
Estimation of Moisture Ratio and Specific Energy Consumption for Apple Slices Drying by Convective and Microwave Methods using Neural Network Modeling
}

\author{
Vali Rasooli Sharabiani ( $\sim$ vrasooli@uma.ac.ir) \\ University of Mohaghegh Ardabili \\ Abdi Roozbeh \\ University of Mohaghegh Ardabili \\ Mohammad Kaveh \\ University of Mohaghegh Ardabili \\ Mariusz Szymanek \\ University of Life Sciences in Lublin \\ Wojciech Tanaś \\ University of Life Sciences in Lublin
}

\section{Research Article}

Keywords: Apple, Energy consumption, Drying, Modeling, Artificial neural network

Posted Date: January 6th, 2021

DOI: https://doi.org/10.21203/rs.3.rs-138330/v1

License: (c) (1) This work is licensed under a Creative Commons Attribution 4.0 International License.

Read Full License

Version of Record: A version of this preprint was published at Scientific Reports on April 28th, 2021. See the published version at https://doi.org/10.1038/s41598-021-88270-z. 


\title{
Estimation of Moisture Ratio and Specific Energy Consumption for Apple Slices Drying by Convective and Microwave Methods using Neural Network Modeling
}

\author{
Vali Rasooli Sharabiani ${ }^{1 *}$, Roozbeh Abdi ${ }^{1}$, Mohammad Kaveh ${ }^{1}$, Mariusz Szymanek ${ }^{2 *}$, Wojciech \\ Tanaś $^{2}$

\begin{abstract}
${ }^{1}$ Department of Biosystem Engineering, Faculty of Agriculture and Natural Resources, University of Mohaghegh Ardabili, Daneshgah Street, 56199-11367, Ardabil, Iran

${ }^{2}$ Department of Agricultural, Forest and Transport Machinery, University of Life Sciences in Lublin, Głęboka 28, 20-612 Lublin, Poland

"Corresponding author: vrasooli@uma.ac.ir; mariusz.szymanek@up.lublin.pl
\end{abstract}

\begin{abstract}
Two different drying methods were applied for dehydration of apple, i.e., convection drying (CD) and microwave drying (MD). The process of convection drying through divergent temperatures; 50,60 and $70{ }^{\circ} \mathrm{C}$ at $1.0 \mathrm{~m} / \mathrm{s}$ air velocity and three different levels of microwave power $(90,180$, and $360 \mathrm{~W}$ ) were studied. In the analysis of the performance of our approach on moisture ratio of apple slices, artificial neural networks (ANNs) was used to provide with a background for further discussion and evaluation. In order to evaluate the models mentioned in the literature, the Midilli et al. model was proper for dehydrating of apple slices in both $\mathrm{MD}$ and $\mathrm{CD}$. The microwave drying technology enhanced the drying rate when compared with convective drying significantly. Effective diffusivity of moisture in CD drying $\left(1.95 \times 10-7-4.09 \times 10-7 \mathrm{~m}^{2} / \mathrm{s}\right)$ was found to be lower than that observed in MD

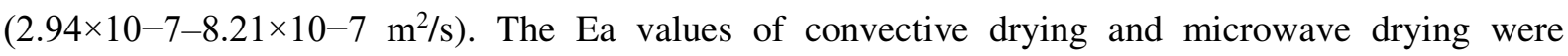
$122.28-125 \mathrm{~kJ} / \mathrm{mol}$ and $14.01-15.03 \mathrm{~W} / \mathrm{g}$ respectively. The MD had the lowest SEC as compared to CD drying methods. According to ANN results, the best values for predication of MR in CD and MD were 0.9993 and 0.9990 , respectively.
\end{abstract}

Keywords: Apple; Energy consumption; Drying; Modeling; Artificial neural network; 


\section{Nomenclature}

\begin{tabular}{|c|c|c|c|}
\hline$M C$ & $\begin{array}{l}\text { Moisture content }\left(\begin{array}{lll}\mathrm{g} & \text { water } \\
\text { matter }\end{array}\right)\end{array}$ & $D_{0}$ & Constant number \\
\hline$W_{x}$ & Initial weight of sample (g) & $\boldsymbol{P}$ & $\begin{array}{l}\text { Output power of microwave } \\
\text { (W) }\end{array}$ \\
\hline$W$ & $\begin{array}{l}\text { Amount of evaporated moisture } \\
(\mathrm{g})\end{array}$ & $E_{a(m)}$ & $\begin{array}{l}\text { Energy of activation in } \mathrm{MD} \\
\text { method }(\mathrm{W} / \mathrm{g})\end{array}$ \\
\hline$W_{y}$ & Dry matter content of sample (g) & $m$ & Weight of raw sample (g) \\
\hline $\mathrm{M}_{\mathrm{t}}$ & $\begin{array}{l}\mathrm{MC} \text { at any time }\left(\mathrm{kg}_{\text {water }} / \mathrm{kg} \text { dry }\right. \\
\text { matter }\end{array}$ & $S E C_{m i c}$ & $\begin{array}{l}\text { Specific energy consumption in } \\
\text { MD method }\end{array}$ \\
\hline $\mathrm{M}_{\mathrm{e}}$ & Equilibrium MC & $P_{m i c}$ & Microwave output power (W) \\
\hline $\mathrm{M}_{0}$ & Initial MC ( $\left.\mathrm{kg}_{\text {water }} / \mathrm{kg}_{\text {dry matter }}\right)$ & $t_{1}$ & Drying time $(\mathrm{s})$ \\
\hline$R^{2}$ & Coefficient of determination & $m_{w}$ & Mass of evaporated water $(\mathrm{kg})$ \\
\hline$R M S E$ & Root mean square error & $S E C_{c o n}$ & $\begin{array}{l}\text { Specific energy consumption in } \\
\text { CD method }\end{array}$ \\
\hline$\chi^{2}$ & Chi square & $C_{p v}$ & $\begin{array}{l}\text { Vapor specific heat capacity } \\
\left(1004.16 \mathrm{~J} /\left(\mathrm{kg}^{\circ} \mathrm{C}\right)\right)\end{array}$ \\
\hline$M R_{\text {exp }, i}$ & Experimental value & $C_{p a}$ & $\begin{array}{l}\text { Air specific heat capacity } \\
\left(1828.8 \mathrm{~J} /\left(\mathrm{kg}^{\circ} \mathrm{C}\right)\right)\end{array}$ \\
\hline$M R_{p r e, i}$ & Predicted value & $Q$ & $\begin{array}{l}\text { Inlet air to drying chamber } \\
\left(\mathrm{m}^{3} / \mathrm{min}\right)\end{array}$ \\
\hline$N$ & Number of observations & $t_{2}$ & Total drying time (min) \\
\hline$Z$ & Constants & $h_{a}$ & $\begin{array}{l}\text { Absolute air humidity } \\
\left(\mathrm{kg}_{\text {vapor }} / \mathrm{kg}_{\text {dry air }}\right)\end{array}$ \\
\hline$D_{e f f}$ & $\begin{array}{l}\text { Effective moisture diffusivity } \\
\left(\mathrm{m}^{2} / \mathrm{s}\right)\end{array}$ & $T_{\text {in }}$ & $\begin{array}{l}\text { Inlet air to drying chamber } \\
\text { temperature }\left({ }^{\circ} \mathrm{C}\right)\end{array}$ \\
\hline$M$ & Material MC ( $\left.\mathrm{kg}_{\text {water }} / \mathrm{kg}_{\text {dry matter }}\right)$ & $T_{a m}$ & Ambient air temperature $\left({ }^{\circ} \mathrm{C}\right)$ \\
\hline$L$ & Half of the slab thickness (m) & $m_{v}$ & Mass of removal water $(\mathrm{kg})$ \\
\hline$i$ & Positive integer & $V_{h}$ & Specific air volume $\left(\mathrm{m}^{3} / \mathrm{kg}\right)$ \\
\hline$t$ & Drying time $(\mathrm{s})$ & $\Delta E$ & Total color differences \\
\hline$E_{a(c)}$ & $\begin{array}{l}\text { Energy of activation in } \mathrm{CD} \\
\text { method }(\mathrm{kJ} / \mathrm{mol})\end{array}$ & $\Delta L^{*}$ & Lightness difference \\
\hline$R_{g}$ & $\begin{array}{l}\text { Universal gas constant }(8.3143 \\
\mathrm{kJ} / \mathrm{mol})\end{array}$ & $\Delta a *$ & Intensity of the color red \\
\hline$T_{a}$ & Absolute air temperature (K) & $\Delta b^{*}$ & Intensity of the color yellow \\
\hline$U_{n}$ & Normalized value & & \\
\hline$U_{R}$ & Actual value & & \\
\hline$U_{\max }$ & Maximum of the actual value & & \\
\hline$U_{\min }$ & Minimum of the actual value & & \\
\hline
\end{tabular}




\section{Introduction}

Apple (Malus domestica Borkh.) is one of the oldest fruits known to mankind and has grown to nourish it. It is one of the most important horticultural products in the world, and countries such as China, the United States, Turkey, Poland, India, the Russian Federation and Iran are considered as major apple producers. Apples, like many other fruits, have a high water content (80-85\% on w.b.). Apple is rich in vitamins, minerals and fiber and is usually consumed raw, but it is used in many foods (especially desserts) and beverages ${ }^{1,2,3}$. Drying, in addition to being a way to increase the shelf life of foods, is known as a way to increase the value added of food products. Removing water from a product under controlled conditions reduces the moisture content of the food to a certain extent, which lessens the activity of enzymes, the rate of undesirable chemical changes and microbial growth. Also, the decrease in moisture is accompanied by a reduction in volume and weight, which is one of the important factors for transportation and maintenance ${ }^{4}$. Throughout the decades, hot air drying method has been one of the most long-established technologies in the food industries. The process of hot air drying includes both the heat and mass transfer while the water is provided by the agricultural products through diffusion. However the total energy of this diffusion goes hand in hand with air temperature, time and air velocity ${ }^{5}$. One of the methods that has been given a lot of attention during the last decade is drying using microwave radiation. Microwave beams are electromagnetic beams with a long wavelength of $2450 \mathrm{MHz}$. During the passing of these waves from the tissue of matter, polar molecules, such as water and salts, vibrate, and this vibration causes the microwave energy to be converted into heat. Unlike other methods of drying, in which heat should penetrate from the surface to depth, in this method heat is produced in the tissue of the food itself and it is prevented from damaging the superficial parts of the food ${ }^{6,7}$. Different methods are used to reduce the moisture content of fruits and vegetables. Izli and $\mathrm{Isik}^{8}$ used microwave, convective, and microwave-convective dryers to dry tomatoes. They showed that microwave-convective dryers require less time to dry tomatoes. Seremet et al. ${ }^{9}$ investigated effect of different drying methods (Hot air convection and hot air convection- microwave dryer) on weight loss and rehydration of sliced pumpkin. Drying of sorbus fruits by convective $\left(50^{\circ} \mathrm{C}\right.$ and $70^{\circ} \mathrm{C}$ at air velocity of $\left.0.3 \mathrm{~m} / \mathrm{s}\right)$ and microwave $(90,160$ and $350 \mathrm{~W})$ were studied in order to determine the drying behaviors. The results showed that the temperature of 50 ${ }^{\circ} \mathrm{C}$ and the microwave power of $90 \mathrm{~W}$ had the slightest variations in color. Also, the lowest specific energy consumption were $0.69 \mathrm{kWh} / \mathrm{kg}$ and $37.07 \mathrm{kWh} / \mathrm{kg}$ respectively at $70^{\circ} \mathrm{C}$ and $350 \mathrm{~W}^{10}$. The correlation of the unpredictable input and output process parameters interconnection follows the stimulated computing approach named Artificial Neural Network (ANN) ${ }^{11}$. ANNs are capable of modeling nonlinear and complex systems with a large number of input and output data. The ability to predict a neural network is completely dependent on its structure (type of activation function, number of layers and number of hidden layer neurons $)^{12.13}$. In recent years, methods based on ANNs have been 
used to predict the moisture content of many food and agriculture products during the drying process, including green peas, tomatoes, corn and pomegranate seeds ${ }^{14-17}$. In this research, the neural network modeling method was used to estimate the moisture ratio of apple slices during drying in microwave and hot air dryer. The results of this model are compared with the results of mathematical modeling to determine its effectiveness. Also, moisture diffusion coefficient, activation energy, specific energy consumption and color changes were also determined for apple slices.

\section{Material and methods}

\subsection{Sample preparation}

Apple was supplied from one of apple orchards of Ardabil city, Iran, in September 2016. Generally, apple samples of uniform sizes were selected. The apple fruit were cleaned and stored in a refrigerator at $4 \pm 1^{\circ} \mathrm{C}$. The premature and spoiled apple was separated manually. The initial MC of apple slices was measured by oven drying method. Apple slices to the nearest $40 \mathrm{~g} \mathrm{(4} \mathrm{mm} \mathrm{thickness} \mathrm{and} 36 \mathrm{~mm}$ diameter) in triplicate samples were dehydrated at $70 \pm 1^{\circ} \mathrm{C}$ for $24 \mathrm{~h}^{18}$. Apple fruit with average initial MC of $45 \%$ (d.b.) was selected for drying material.

\subsection{Experimental procedure}

\subsubsection{Convective dryer}

Convective drying (CD) was conducted by using laboratory drying oven (BF55E; FG Co., Iran). The velocity of the air approaching to the apple samples was measured by an anemometer (Lutron AM4202; Electronic Enterprise Co., Taipei, Taiwan) with $\pm 0.1 \mathrm{~m} / \mathrm{s}$ accuracy and the average air velocity was $1.2 \pm 0.02 \mathrm{~m} / \mathrm{s}$. Electrical heating unit of this dryer equipped with PT100 thermometer sensor and PID controller with $\pm 0.1 \mathrm{C}$ accuracy. Average humidity and air temperature of ambient air during convection dryer were $30 \%$ and $26^{\circ} \mathrm{C}$, respectively.

\subsubsection{Microwave dryer}

A fully programmable microwave oven (Panasonic NN-CD997S Microwave Oven) with maximum output of $1000 \mathrm{~W}$ was utilized for this study. The microwave oven has the capability of operating at different microwave output powers, 90, 180, 270, 360, 450, 540, 630, 720, 900 and $1000 \mathrm{~W}$. The microwave drying area is $462 \mathrm{~mm}, 242 \mathrm{~mm}$ and $412 \mathrm{~mm}$ inner size and includes a $380 \mathrm{~mm}$ diameter rotary glass plate at the oven base. The microwave output power and processing time was set fully by using digital control panel of microwave oven.

\subsection{Experimental setup}

\subsubsection{Determination of moisture ratio}


Drying curves may be represented in different ways; MC (wet and dry base) versus time, drying rate versus time, or drying rate versus MC. The MC of apple was calculated by using Equation $1{ }^{19}$; Equation 2 was used for calculating the moisture ratio of apple slices ${ }^{20}$ :

$$
\begin{aligned}
& M C=\frac{\left(\left(W_{x}-W\right)-W_{y}\right)}{W_{y}} \\
& M R=\frac{\left(M_{t}-M_{e}\right)}{\left(M_{0}-M_{e}\right)}
\end{aligned}
$$

It should be noted that due to the insignificant value of $M_{e}$ in comparison with $M_{t}$ and $M_{0}$, it can be saved, Therefore Equation 2 can be simplified to Equation $3^{21}$ :

$$
M R=\frac{M_{t}}{M_{0}}
$$

\subsubsection{Mathematical modelling of drying curves}

The models listed in Table 1 were used for mathematical modeling drying kinetics of apple slice in $\mathrm{MD}$ and $\mathrm{CD}$. To compare the data to each model, curve expert was used for curve fitting. This software has linear and nonlinear regression models and various interpolation methods. In order to select the suitable drying kinetics descriptor, the statistical parameters of $R^{2}, R M S E$ and $\chi^{2}$ were used. Finally, the drying model with maximum $R^{2}$ and minimum $R M S E$ and $\chi^{2}$ was selected as the appropriate model for describing drying kinetics. The mentioned statistical parameters are defined by the following equations ${ }^{22.23}$ :

$$
\begin{aligned}
& R^{2}=1-\frac{\sum_{i=1}^{N}\left[M R_{\text {exp }, i}-M R_{p r e, i}\right]^{2}}{\sum_{k=1}^{N}\left[\frac{\sum_{k=1}^{n} M R_{p r e, i}}{N}-M R_{p r e, i}\right]^{2}} \\
& \chi^{2}=\frac{\sum_{i=1}^{N}\left(M R_{\text {exp }, i}-M R_{p r e, i}\right)^{2}}{N-z} \\
& R M S E=\left[\frac{1}{N} \sum_{i=1}^{N}\left(M R_{p r e, i}-M R_{\text {exp }, i}\right)^{2}\right]^{\frac{1}{2}}
\end{aligned}
$$

Exponential equation form of Equation 2 can be used as follows ${ }^{24}$ :

$$
M R=\frac{M_{t}-M_{e}}{M_{0}-M_{e}}=\exp \left(-k t^{n}\right)
$$


Table 1. Mathematical empirical drying models given by various authors for the drying curves

\begin{tabular}{llc}
\hline Models & Equation & References \\
\hline Midlli et al. & $M R=a \exp \left(-k t^{n}\right)+b t$ & 25 \\
Page & $M R=\exp \left(-k t^{n}\right)$ & 27 \\
Logistic & $M R=a /(1+b \exp (k t))$ & 28 \\
Two-term & $M R=a \exp \left(-k_{0} t\right)+b \exp \left(-k_{1} t\right)$ & 29 \\
Logarithmic & $M R=a \exp (-k t)+c$ & 29 \\
\hline
\end{tabular}

\subsubsection{Effective moisture diffusivity}

Mass transfer during food drying is a complex process involving various mechanisms such as molecular penetration, movement in capillary tubes, and liquid penetration in the porous materials, penetration of vapor in air pores and hydrodynamic flow, or surface propagation. Moisture penetration is one of the most important factors controlling the drying process. When different mechanisms are effective in transmitting, it is difficult to examine each mechanism and measure the mass transfer rate in each one. Hence, in such processes, the description of effective diffusion is used and its concept is described by the Fik's second law as follows ${ }^{30}$ :

$$
\frac{\partial M}{\partial t}=D_{e f f} \nabla^{2} M
$$

Calculation of effective diffusion coefficient using the Fik's second law is a tool for describing the drying process and possible mechanisms for the transfer of moisture within food products. The analytical solution of Fik's law is as follows ${ }^{31}$ :

$$
M R=\frac{M_{t}-M_{e}}{M_{0}-M_{e}}=\frac{8}{\pi^{2}} \sum_{n=0}^{\infty} \frac{1}{(2 i+1)^{2}} \exp \left(-\frac{(2 i+1)^{2} \pi^{2}}{4 L^{2}} D_{e f f} t\right)
$$

Where $\mathrm{i}$ is a positive integer that is equal to 1 for long drying time. Therefore, Equation 9 can be written in simpler form as Equation 10:

$$
M R=\frac{8}{\pi^{2}} \exp \left(-\frac{\pi^{2} D_{e f f} t}{4 L^{2}}\right)
$$

The coefficient $K_{1}$ is calculated by plotting the curve $\ln (M R)$ versus time, in accordance with Equation 11 as follows ${ }^{32}$ :

$$
K_{1}=\left(\frac{D_{e f f} \pi^{2}}{4 L^{2}}\right)
$$




\subsubsection{Activation energy}

Dependence of the diffusion coefficient with temperature is shown using the Arrhenius equation (Equation 12). Activation energy of the convective dryer $\left(E_{a(c)}\right)$ was determined by plotting the effective moisture diffusion coefficient curve versus absolute air temperature reversal ${ }^{33}$.

$$
D_{e f f}=D_{0} \exp \left(\frac{E_{a(c)}}{R_{g} T_{a}}\right)
$$

The linear form of Equation 12 can be obtained by applying the logarithms as:

$$
\ln \left(D_{e f f}\right)=\ln \left(D_{0}\right)-\left(\frac{E_{a(c)}}{R_{g}} \cdot \frac{1}{T_{a}}\right)
$$

$K_{2}$ can be obtained by plotting $\ln \left(D_{e f f}\right)$ versus $\frac{1}{T_{a}}$ :

$$
K_{2}=\frac{E_{a(c)}}{R_{g}}
$$

Linear regression analyses were used to fit the equation to the experimental data to obtain correlation coefficient $\left(\mathrm{R}^{2}\right)$.

The activation energy for microwave dryer $\left(E_{a(m)}(\mathrm{W} / \mathrm{g})\right)$ was calculated by using a correlation between effective moisture diffusivity and $\left(\frac{m}{P}\right)$ is taken into account ${ }^{34}$ :

$$
D_{e f f}=D_{0} \exp \left(-\frac{E_{a(m)} m}{P}\right)
$$

$E_{a(m)}$ may be accomplished using one of several methods as follows:

$$
\ln \left(D_{\text {eff }}\right)=\ln \left(D_{0}\right)-\left(\frac{E_{a(m)}}{P} \cdot m\right)
$$

Following plotting of $\ln \left(D_{\text {eff }}\right)$ versus $(1 / \mathrm{P}), K_{3}$ is calculated for the microwave as follows:

$$
K_{3}=\frac{E_{a(m)}}{P}
$$

\subsubsection{Specific energy consumption}

The specific energy consumed during the drying process, which is the amount of energy used to evaporate one kilogram of water from the product, was obtained using Equation 18 under microwave drying method $^{35}$ :

$$
S E C_{m i c}=60 \frac{P_{m i c} t_{1}}{m_{w}}
$$


Specific energy consumption $\left(S E C_{c o n}\right)$ of apple slice in $\mathrm{CD}$ approach was measured through the Equation 19 as follows ${ }^{36,37}$ :

$$
S E C_{c o n}=\left(C_{p a}+C_{p v} h_{a}\right) Q t_{2} \frac{\left(T_{i n}-T_{a m}\right)}{m_{v} V_{h}}
$$

\subsubsection{Color}

Three color schemes, including RGB, CMYK and Lab, are used to determine the color of food. The Lab model is often used for food color research studies. L demonstrates brightness in the range 0-100, and two colored components $(-120-+120)$ including a (greenness to redness) and b (blueness to yellowness). The color parameters of apple slice were measured using digital portable colorimeter (CR-10-PLUS, Konica Minolta Co, Japan), appropriate test method based on CIELAB. Total color changes $(\Delta E)$ was calculated using Equation 20. All color changes were obtained with averaging in six replicates samples ${ }^{38,39}$ :

$$
\Delta E=\left[\left(\Delta L^{*}\right)^{2}+\left(\Delta b^{*}\right)^{2}+\left(\Delta a^{*}\right)^{2}\right]^{0.5}
$$

\subsubsection{ANN}

ANN was used for modeling the drying process of apple slice in microwave and hot air dryer to predict MR by using Matlab software. In this research, the Levenberg-Marquard optimization method was used to learn the network. The inputs for ANN model are drying time, and drying chamber inlet air temperature, and the output is MC variations of apple slice. Figure 1 shows ANN inputs and output structure with two hidden layers.

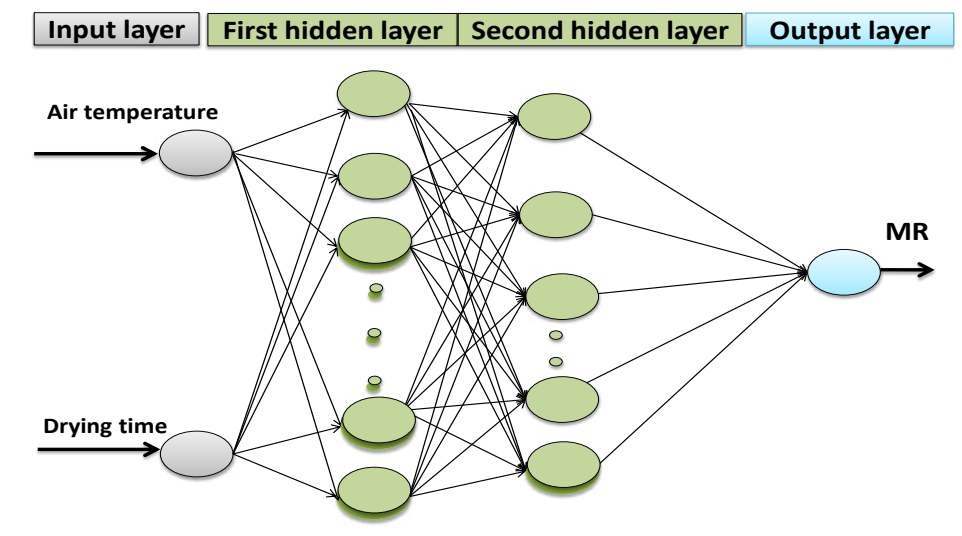

Figure 1. Four-layer ANN inputs and output structure used in this study

\subsubsection{Convective dryer}

Apple slice drying experiments were done at 50,60 and $70^{\circ} \mathrm{C}$ set temperature. The two input parameters had applied in the experiments with convective dryer. The moisture ratio (MR) values were derived. Networks with two neurons in the input layer (air temperature and drying time) and one 
neuron in the output layer (MR) were designed. In this part, the total data of, moisture ratio (163 data) for artificial neural networks were used. In the first group, 70\% (115 data) were taken for training phase and in the second group 30\% (48 data) for testing, chosen randomly from the set of 163 data.

\subsubsection{Microwave dryer}

Applying the two inputs in all experiments, the moisture ratio values obtained for different conditions. Networks with two neurons in input layer (microwave power and drying time) and one neuron in output layer (MR) were designed. About 70\% (49 data) of the all experimental data (70 data) were separated for network training to find suitable structure. Prior to training the neural network, input data normalized to it. The purpose of normalizing is to convert data between zero and one. Therefore, the following equation was used for normalization ${ }^{40}$ :

$$
U_{n}=\frac{U_{R}-U_{\min }}{U_{\max }-U_{\min }}
$$

In order to evaluate the accuracy and performance of the developed models of artificial neural networks, the statistical criteria of the coefficient of determination $\left(\mathrm{R}^{2}\right)$, root mean square error (RMSE) and mean absolute error (MAE) were used. The mentioned statistical parameters calculated using the following equations ${ }^{41}$ :

$$
\begin{aligned}
& M S E=\frac{1}{m q} \sum_{p=1}^{m} \sum_{i=1}^{q}\left(S_{i p}-T_{i p}\right)^{2} \\
& R^{2}=1-\frac{\sum_{k=1}^{m}\left[S_{k}-T_{k}\right]}{\sum_{k=1}^{m}\left[S_{k}-\frac{\sum_{k=1}^{n} S_{k}}{n}\right]} \\
& M A E=\frac{100}{n} \sum_{k=1}^{m}\left|\frac{S_{k}-T_{k}}{T_{k}}\right|
\end{aligned}
$$

\section{Results and discussion}

\subsection{Drying characteristics (Convective and microwave drying kinetics)}

Changes in moisture ratio of apple slice with drying time at different air temperatures 50,60 , and $70^{\circ} \mathrm{C}$ and air velocity $1 \mathrm{~m} / \mathrm{s}$ were presented in Figure 2a. The drying experiments of apple slices continued until the moisture content of the samples reached about 0.18 (d.b.) in both drying methods. As can be seen in Figure 2a, increase of air temperature from 50 to $70{ }^{\circ} \mathrm{C}$ causes a decrease on final product drying time, which is consistent with the results of Beigir ${ }^{42}$ and Kaleta et al. ${ }^{43}$. In the process of convective drying, increasing air temperature from 50 to $70{ }^{\circ} \mathrm{C}$ resulted to increase in mass transfer, reduce process time and energy consumption ${ }^{44}$. Drying time for apple slice in air velocity $1 \mathrm{~m} / \mathrm{s}$, were 200, 150 and $100 \mathrm{~min}$ at 50,60 and $70^{\circ} \mathrm{C}$, respectively. Kara and Doymaz ${ }^{44}$ reported that the drying times of apple pomace at air velocity $1 \mathrm{~m} / \mathrm{s}$ for four air temperatures $50,60,70$ and $80^{\circ} \mathrm{C}$. An 
increment in air temperature caused also a decrease in drying time at apple pomace. Beigi ${ }^{42}$ reported that air temperature had a shorter effect on drying time in Hot air drying of apple slices at $1.5 \mathrm{~m} / \mathrm{s}$ air velocity 50, 60 and $70^{\circ} \mathrm{C}$. Effect of air temperature $\left(50,65,80\right.$ and $\left.90^{\circ} \mathrm{C}\right)$, three levels of drying product thickness (3,5, and $7 \mathrm{~mm})$, engine load levels $(25,50,75$, and $100 \%)$, and air velocity $(1 \mathrm{~m} / \mathrm{s})$ on moisture ratio of apple slices in combined heat and power (CHP) dryer have been investigated by Samadi et al. ${ }^{45}$. With increasing of air temperature in the tested range, the amount of moisture removed from apple slices increased.

Changes in MR of apple slice with drying time in microwave dryer at different microwave power (90, 180 and $360 \mathrm{~W}$ ) were shown in Figure 2b. As shown in Figure 2b, it can be seen that the rate of water loss in MD method was higher than $\mathrm{CD}$, due to the electromagnetic heating effect of microwave in drying food products ${ }^{46}$. Also, with higher microwave power, more heat generated within the sample created a larger vapor pressure difference between the center and the product surface. Thus accelerated the interior moisture migration and increased surface water evaporation ${ }^{47}$.

a)

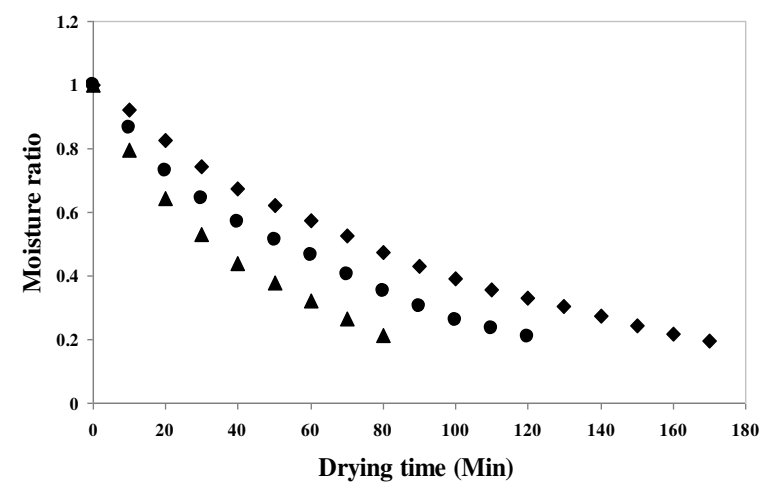

b)

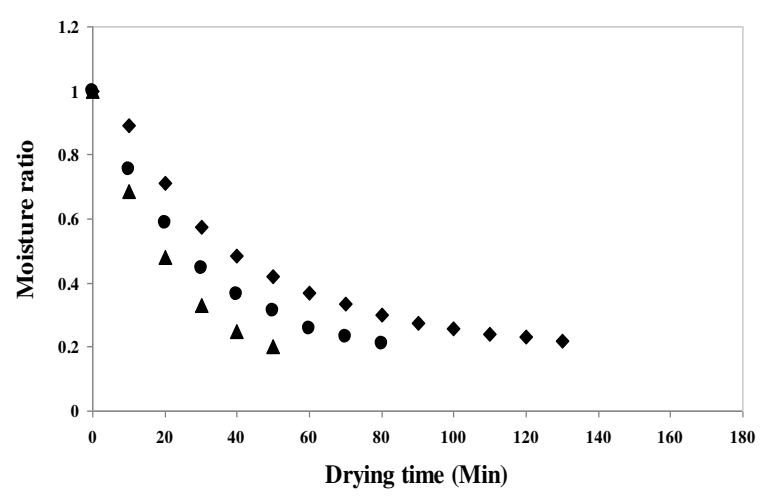

Figure 2. Moisture ratio versus drying time for apple slice under different drying: a) air temperature $\left((\bullet) 50{ }^{\circ} \mathrm{C},(\bullet) 60^{\circ} \mathrm{C},(\Delta) 70{ }^{\circ} \mathrm{C}\right)$; b) microwave powers $((\bullet) 90 \mathrm{~W},(\bullet) 180 \mathrm{~W},(\bullet) 360 \mathrm{~W})$

The times of the drying process in MD were 50, 80 and $130 \mathrm{~min}$ at 360, 180 and $90 \mathrm{~W}$, respectively. The results showed that with increasing microwave power, the drying time had a downward trend. Similar results were obtained for drying crops in a microwave dryer such as pomegranate arils ${ }^{48}$, mushroom, tomatoes ${ }^{8}$ and broccoli stalk slice ${ }^{49}$.

In order to mathematical modeling of apple slice drying kinetics in the convective dryer, five commonly mathematical models for thin layer products were used (Table 1). For all convective drying experiments $\left(50,60\right.$ and $70^{\circ} \mathrm{C}$ air temperature and 1 air velocity), determination coefficient $\left(R^{2}\right)$, root mean square error (RMSE), and reduced Chi square $\left(\chi^{2}\right)$ values ranged between 0.9932-0.9999, 0.0172-0.0845 and 0.0003-0.0468, respectively. From Table 2, Midilli et al. model had the highest $R^{2}$ (0.9994- 0.9999) and the lowest RMSE (0.0194- 0.0274) and $\chi^{2}(0.0004-0.0041)$ values. Therefore, the Midilli et al. drying model was achieved as appropriate one for describing drying behaviors of apple slices. Chayjan et al. ${ }^{50}$ tested five empirical models (Midili et al., Demir et al., 
Logistics, Logarithmic and Wang and Singh) in their research for continuous band drying of eggplant slices and claimed that all models described well drying kinetics at studied air temperatures, air velocities and infrared power. Midili et al. model was chosen as the best model for describing the moisture ratio of the sour cherry. Torki-Harchegani et al. ${ }^{51}$ examined the kinetics of drying lemon slices in convective dryer at 50,60 and $75^{\circ} \mathrm{C}$ air temperature. Their results showed that the drying temperature had a significant effect on the drying time and drying rate. Among the models used, the Midilli et al. model was proposed as the best model for prediction moisture content of lemon slices.

Table 2. The statistical comparison for prediction drying of apple slices in convective dryer

\begin{tabular}{llllllllll}
\hline Model & \multicolumn{4}{c}{$R^{2}$} & \multicolumn{3}{c}{$\chi^{2}$} & \multicolumn{3}{c}{$R M S E$} \\
\cline { 2 - 10 } & $\mathbf{5 0}^{\circ} \mathbf{C}$ & $\mathbf{6 0}^{\circ} \mathbf{C}$ & $\mathbf{7 0}^{\circ} \mathbf{C}$ & $\mathbf{5 0}^{\circ} \mathbf{C}$ & $\mathbf{6 0}^{\circ} \mathbf{C}$ & $\mathbf{7 0}^{\circ} \mathbf{C}$ & $\mathbf{5 0}^{\circ} \mathbf{C}$ & $\mathbf{6 0}^{\circ} \mathbf{C}$ & $\mathbf{7 0}^{\circ} \mathbf{C}$ \\
\hline Midili et al. & 0.9999 & 0.9998 & 0.9998 & 0.0003 & 0.0009 & 0.0010 & 0.0172 & 0.0211 & 0.0221 \\
Page & 0.9998 & 0.9998 & 0.9996 & 0.0007 & 0.0011 & 0.0014 & 0.0282 & 0.0681 & 0.0741 \\
Logistics & 0.9993 & 0.9991 & 0.9989 & 0.0039 & 0.0059 & 0.0103 & 0.0268 & 0.0302 & 0.0398 \\
Two-term & 0.9966 & 0.9941 & 0.9932 & 0.0222 & 0.0401 & 0.0468 & 0.0629 & 0.0886 & 0.0845 \\
Logarithmic & 0.9998 & 0.9994 & 0.9990 & 0.0018 & 0.0028 & 0.0031 & 0.0224 & 0.0240 & 0.0251 \\
\hline
\end{tabular}

The results of the fitting of apple slices drying data in microwave method with different mathematical models were presented in Table 3. For all microwave drying experiments, $R^{2}, R M S E$ and $\chi^{2}$ values ranged between $0.9966-0.9999 ; 0.0188-0.0421$ and $0.0005-0.0291$. Midili et al. model had the highest $R^{2}(0.9999)$ and the lowest $R M S E(0.0188)$ and $\chi^{2}(0.0005)$ values. Therefore, Midili et al. model was proposed as the best model for drying apple slice in MD. Darvishi et al. ${ }^{52}$ dried white mulberry in microwave drying at 100, 200, 300, 400 and $500 \mathrm{~W}$ power levels and applied the experimental data to five thin layer models where Lewis, Henderson and Pabis, Page, Wang and Singh, and Midilli et al. models, the Page model gives the highest $R^{2}(0.999)$ and lower $R M S E(0.009)$ and $\chi^{2}(0.00009)$ values. Ganesapillai, Murugan $\& \operatorname{Singh}^{53}$ used 100, 180, 300, 450, 600 and $900 \mathrm{~W}$ power levels for dehydration of Ginger rhizomes and to determine the drying characteristics of sample, Henderson, Page, Logarithmic, Wang and Singh, Diffusion, Verma, Twoterm exponential, Midilli models tested. Diffusion model gave the best results (maximum values $R^{2}=$ 0.99958 , minimum values $R M S E(0.00429)$ and $\chi^{2}(0.00019)$.

Table 3. The statistical comparison for prediction drying of apple slices in microwave dryer

\begin{tabular}{lllllclccc}
\hline Model & \multicolumn{4}{c}{$R^{2}$} & \multicolumn{4}{c}{$\chi^{2}$} & \multicolumn{3}{c}{$R M S E$} \\
\cline { 2 - 11 } & $\mathbf{9 0 ~ W}$ & $\mathbf{1 8 0} \mathbf{W}$ & $\mathbf{3 6 0} \mathbf{W}$ & $\mathbf{9 0} \mathbf{W}$ & $\mathbf{1 8 0} \mathbf{W}$ & $\mathbf{3 6 0} \mathbf{W}$ & $\mathbf{9 0} \mathbf{W}$ & $\mathbf{1 8 0} \mathbf{W}$ & $\mathbf{3 6 0} \mathbf{W}$ \\
\hline Midili et al. & 0.9999 & 0.9996 & 0.9994 & 0.0005 & 0.0021 & 0.0027 & 0.0188 & 0.0249 & 0.0251 \\
Page & 0.9994 & 0.9991 & 0.9995 & 0.0057 & 0.0084 & 0.0148 & 0.0279 & 0.0313 & 0.0410 \\
Logistics & 0.9981 & 0.9967 & 0.9967 & 0.0077 & 0.0194 & 0.0272 & 0.0304 & 0.0501 & 0.0596 \\
Two-term & 0.9976 & 0.9974 & 0.9968 & 0.0116 & 0.0243 & 0.0324 & 0.0359 & 0.0564 & 0.0618 \\
Logarithmic & 0.9968 & 0.9979 & 0.9966 & 0.0018 & 0.0051 & 0.0291 & 0.0231 & 0.0268 & 0.0421 \\
\hline
\end{tabular}




\subsection{Effective moisture diffusivity}

Effective moisture diffusivity values $\left(D_{\text {eff }}\right.$ ) of apple slice at different dryer calculated by Equation (10). The Reported $D_{\text {eff }}$ values were within the general range of $10^{-8}$ to $\times 10^{-12} \mathrm{~m}^{2} / \mathrm{s}$ for agricultural product and food materials ${ }^{27}$. In convective drying, minimum $D_{\text {eff }}$ value $\left(1.95 \times 10^{-7} \mathrm{~m}^{2} / \mathrm{s}\right)$ belonged to pretreated apple slice of at air temperature $40^{\circ} \mathrm{C}$, and maximum value $\left(4.09 \times 10^{-7} \mathrm{~m}^{2} / \mathrm{s}\right)$ belonged to apple slice at air temperature $70^{\circ} \mathrm{C}$. Obtained values were demonstrated in Figure 3a. The results indicated direct correlation between $D_{\text {eff }}$ and temperature. Increasing the air temperature was accompanied by an increase in $D_{\text {eff }}$ and a reduction in the drying time. Beigi ${ }^{42}$ estimated as $7.03 \times 10^{-10}$ to $1.08 \times 10^{-9} \mathrm{~m}^{2} / \mathrm{s}$ for apple in convective dryer at $50^{\circ} \mathrm{C}$ and $70^{\circ} \mathrm{C}, 1.5 \mathrm{~m} / \mathrm{s}$ air velocity. The values of $D_{e f f}$ are comparable with the reported values of $1.73 \times 10^{-10}$ to $4.40 \times 10^{-10} \mathrm{~m}^{2} / \mathrm{s}$ for apple pomace at 50 to $80^{\circ} \mathrm{C}$ and air velocity of $2 \pm 0.1 \mathrm{~m} / \mathrm{s}$ in convective dryer ${ }^{44}, 6.97 \times 10^{-11}$ to $2.38 \times 10^{-10} \mathrm{~m}^{2} / \mathrm{s}$ for quince slices drying in convective dryer ${ }^{54}$ and $3.27 \times 10^{-9}$ to $1.23 \times 10^{-8} \mathrm{~m}^{2} / \mathrm{s}$ consideration for broccoli slices with air temperatures of $45-70^{\circ} \mathrm{C}$ and air velocities of $2 \mathrm{~m} / \mathrm{s}$ in convective dryer ${ }^{55}$.

The values of $D_{\text {eff }}$ for microwave dryer are presented in Figure $3 \mathrm{~b}$. In microwave drying, minimum value $\left(2.94 \times 10^{-7} \mathrm{~m}^{2} / \mathrm{s}\right)$ belonged to apple slice which had a microwave power level of $90 \mathrm{~W}$; maximum value $\left(8.21 \times 10^{-7} \mathrm{~m}^{2} / \mathrm{s}\right)$ belonged to apple slice that had a microwave power level of $360 \mathrm{~W}$. According to the results the values of $D_{\text {eff }}$ in MD were higher than CD. Also, the microwave power and lower air velocity can accelerate the water molecules present in the apple slice to evaporate faster, thus providing a faster decrease of the apple slice MC and the corresponding higher value of effective moisture diffusivity ${ }^{37}$.

a)

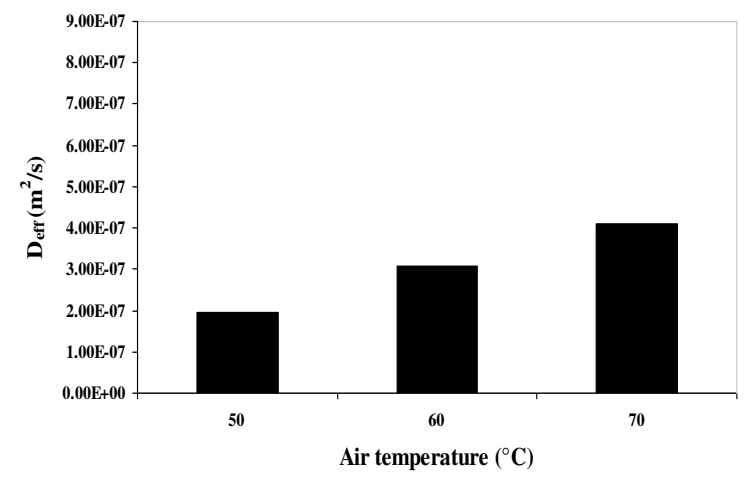

b)

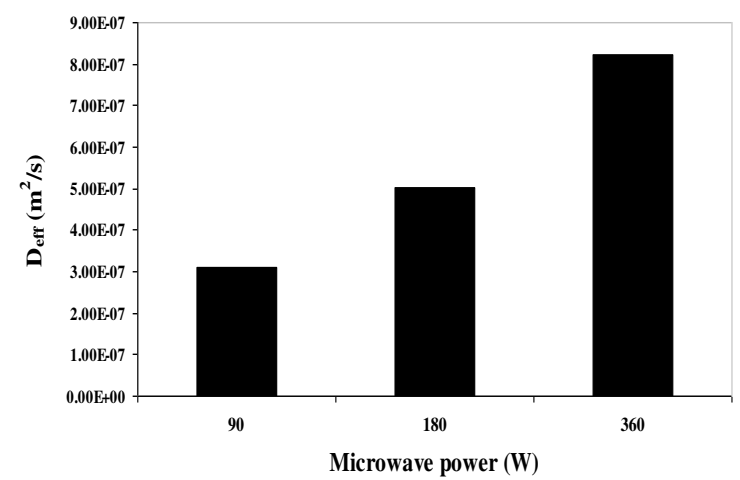

Figure 3. Effective moisture diffusivity ( $D_{\text {eff }}$ ) for drying of apple slice in different: a) air temperature, b) microwave power

Similar results for the amount of $D_{\text {eff }}$ in microwave dryers are provided by other authors for fruits and vegetables. For example: effective moisture diffusivity values for ginger rhizomes was obtained 
ranged from $20.24 \times 10^{-12}$ to $9.8 \times 10^{-11} \mathrm{~m}^{2} / \mathrm{s}$ at $100-900 \mathrm{~W}^{53}, D_{\text {eff }}$ values for bamboo shoot slices increased from $4.15 \times 10^{-10}$ to $22.83 \times 10^{-10} \mathrm{~m}^{2} / \mathrm{s}$ at different power levels ranging from 140 to $350 \mathrm{~W}$ in microwave dryer ${ }^{56}$ and effective diffusivity of mulberry increased with increasing microwave power. It varied from $1.06 \times 10^{-8}$ to $3.45 \times 10^{-8} \mathrm{~m}^{2} / \mathrm{s}$ at five microwave powers of $100,200,300,400$ and 500 $\mathrm{W}^{57}$.

\subsection{Activation energy}

During the drying process, the highest values of activation energy for CD and MD methods were obtained $125 \mathrm{~kJ} / \mathrm{mol}$ and $15.03 \mathrm{~W} / \mathrm{g}$, respectively (Table 4). The air temperature and microwave power were important factors influencing the effective moisture diffusivity and activation energy. By increasing the temperature and microwave power, the activation energy was reduced as the result of mass transfer and more moisture loss of apple slice. The obtained results are in line with the stated values for hot air drying of cherry tomato $(31.99$ and $36.21 \mathrm{~kJ} / \mathrm{mol}$ for the raw and blanched cherry tomatoes $^{5}$, and microwave drying of kiwi slices (17.96-21.38 W/g $)^{57}$.

Table 4. The estimated activation energy in convective and microwave dryer

\begin{tabular}{llll}
\hline Air temperature $\left({ }^{\circ} \mathrm{C}\right)$ & $\mathbf{5 0}$ & $\mathbf{6 0}$ & $\mathbf{7 0}$ \\
\hline Ea $(\mathrm{kJ} / \mathrm{mol})$ & 125 & 124.44 & 122.28 \\
\hline Microwave power $(\mathrm{W})$ & 90 & 180 & 360 \\
\hline Ea $(\mathrm{W} / \mathrm{g})$ & 15.03 & 14.50 & 14.01 \\
\hline
\end{tabular}

\subsection{Specific energy consumption (convection and microwave)}

Figure 4a shows the specific energy consumption of drying process of apple slice in convection dryer. In this study, the specific energy consumption was obtained in the range of 122.77 to $174.67 \mathrm{MJ} / \mathrm{kg}$. According to the results, the highest and lowest energy values were consumed in the process of drying apple slices at 50 and $70^{\circ} \mathrm{C}$, respectively. As shown in Figure $4 \mathrm{a}$, the increase in the air temperature of the dryer chamber from 50 to $70^{\circ} \mathrm{C}$ continuously reduces energy consumption. In spite of lowering the specific heat of the air at higher temperatures, because of the significant reduction in the process time at these temperatures, the increase in the air temperature of the dryer chamber decreases the amount of energy consumed by the process. The values of $S E C$ are comparable with the reported values of 74.73 $\mathrm{MJ} / \mathrm{kg}$ mentioned for fluidized bed drying of rough rice ${ }^{58}$, average specific energy consumption for potato in convection dryer was obtained $3.491 \mathrm{MJ} / \mathrm{kg}^{59}$.

As shown in Figure 4b, during the drying process of apple slices in microwave dryer, the specific energy consumption at 90 and $360 \mathrm{~W}$ microwave power were obtained 80.05 and $52.03(\mathrm{MJ} / \mathrm{kg})$, respectively. In other words, the ratio of highest to lowest value of specific energy consumption was 1.53. According to the results, with the increase in microwave power, the specific energy consumption dropped significantly. The reduction in specific energy consumption at higher microwave power in MD method is due to the effect of its volumetric heating, which reduces the drying time ${ }^{37}$. Advantages such as shorter drying times and lower energy consumption were the key drivers for the further 
development of the microwave drying technique. The minimum value of $S E C$ for drying of sunflower seeds were obtained to be $5.81 \mathrm{MJ} / \mathrm{kg}$ at microwave power $300 \mathrm{~W}^{35}$ and the maximum and minimum values of energy consumption in microwave drying for tomato were obtained to be 350 and $8.4 \mathrm{Wh}$, respectively at range $90-600 \mathrm{~W}^{60}$.

a)

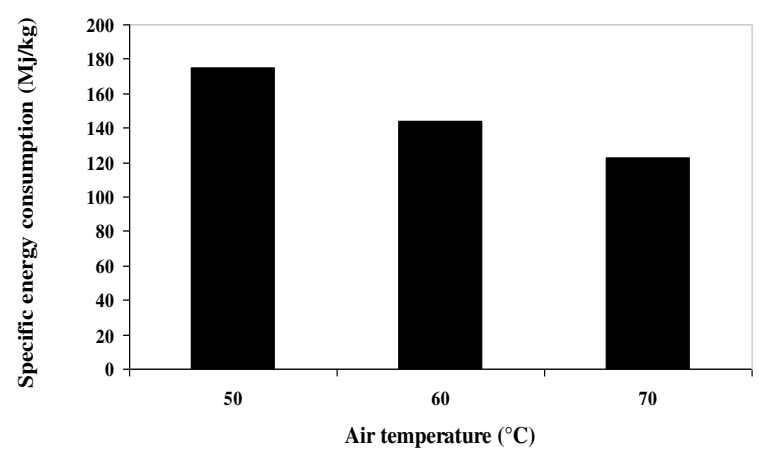

b)

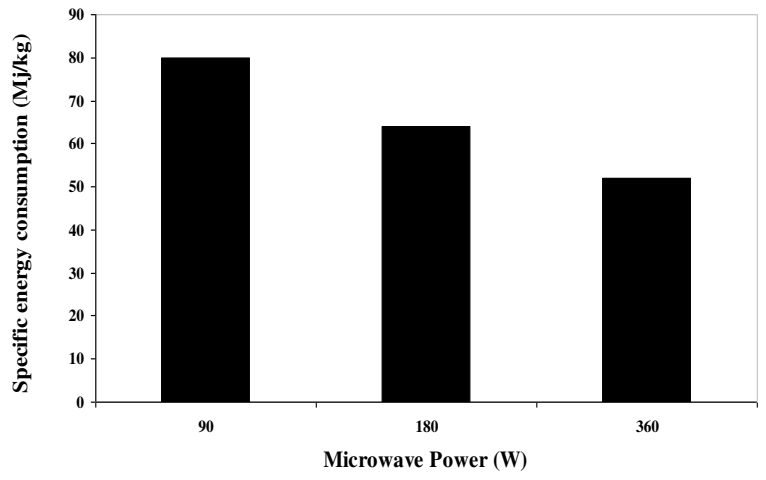

Figure 4. Variations of specific energy consumption for drying process of apple slice in different: a) air temperature, b) microwave power

\subsection{Color for (convection and microwave)}

Color is one of the most important qualitative properties of fresh, processed food and its marketing. As shown in Figure $5 \mathrm{a}$, color variations $(\Delta E)$ at different temperatures of 50,60 and $70^{\circ} \mathrm{C}$ are shown in convective dryer. The most and the least amount of color variations ( $\Delta E$ ) occurred at temperatures of 70 and $50^{\circ} \mathrm{C}$, respectively. According to the results, with the increase in air temperature of the dryer, the amount of color changes $(\Delta E)$ increased due to the decrease in moisture content in apple slice and the shrinkage process ${ }^{61}$. During the drying process, oxidation occurs and as a result of this oxidation, the intensity of the color decreases. The color change $(\Delta E)$ of pomegranates arils $(6.80-14.16 \mathrm{~N})$ at hot air dryer were reported by Horuz and Maskan ${ }^{48}$. The minimum color change (9.316) was obtained at air velocity of $2 \mathrm{~m} / \mathrm{s}$, air temperature $\left(60^{\circ} \mathrm{C}\right)$ and belt linear speed of $2.5 \mathrm{~mm} / \mathrm{s}$, while the maximum color change was $18.24 \mathrm{MJ} / \mathrm{kg}$ observed at $1.5 \mathrm{~m} / \mathrm{s}$ air velocity, air temperature $40^{\circ} \mathrm{C}$ and belt linear speed $(\mathrm{mm} / \mathrm{s})$ of $10.5 \mathrm{~mm} / \mathrm{s}$, for terebinth ${ }^{36}$.

As shown in Figure 5b, color changes in microwave dryer increased by increasing microwave power from 90 to $180 \mathrm{~W}$. The microwave power and process time are the effective factors influencing the color change in the microwave dryer. Due to the heat, the chlorophyll green pigments may turn into pheophytin, which has a brownish color. The change in the color of the pigments can be due to the effect of heat on heat-sensitive compounds such as carbohydrates, proteins and vitamins, which also causes color change during the drying process ${ }^{62}$. 

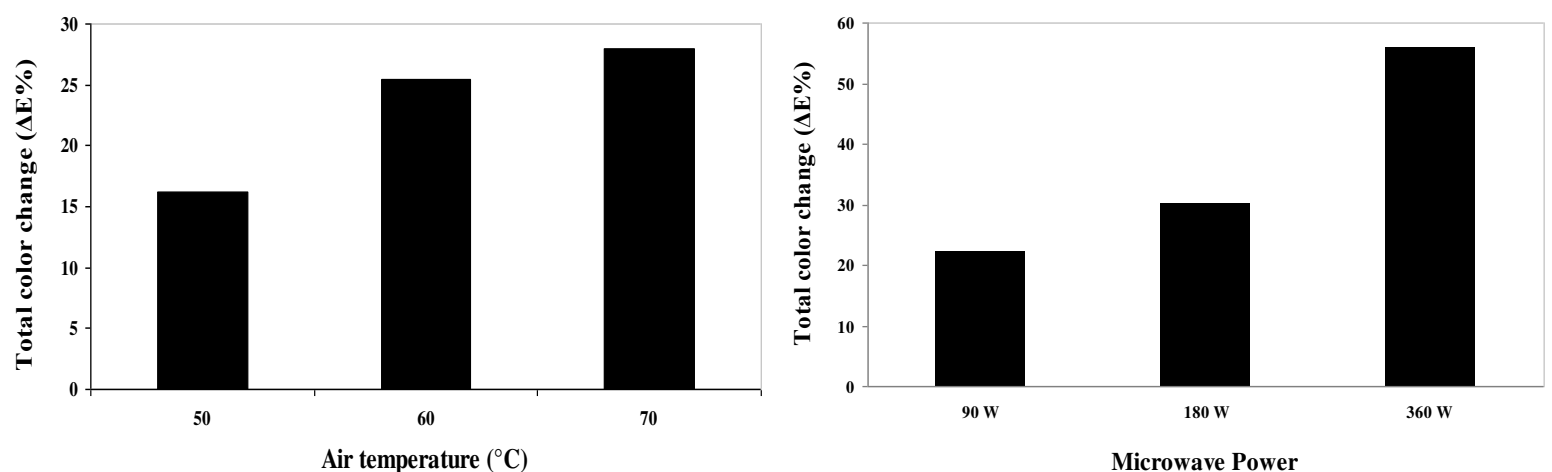

Figure 5. Color change values of apple slices in different a) air temperature, b) microwave power

\subsection{ANN}

\subsubsection{Convective dryer}

Table 5 presents the best results for combining CFBF and FFBF networks with different topologies and activation functions to predict the moisture ratio of apple slices in CD method. According to Table 5, we can get the best performance of the FFBF network, which with the topology 2-10-10-1, along with the TAN, TAN and PUR threshold function and LMA (Levenberg-Marquardt algorithm) for training neural network, has the best result through the three-layer and four-layer topologies. The selected topology created the highest level of correlation (0.9993 for train and 0.9994 for test) and the lowest values of MAE and MSE achieved were 0.0047 for train, 0.0041 for test and 0.00044 respectively, for output variables. Tavakolipour et al. ${ }^{63}$, the moisture ratio of zucchini were predicted by using artificial neural networks at convective dryer. According to the results, the coefficient of determination 0.998 and the RMSE value (0.0335) for the moisture ratio was obtained.

Table 5. The best values of evaluation criteria for FFBF and CFBF networks in different conditions of the number of layers and threshold functions for MR in convective dryer

\begin{tabular}{|c|c|c|c|c|c|c|c|c|}
\hline \multirow[t]{2}{*}{ Network } & \multirow{2}{*}{$\begin{array}{l}\text { Training } \\
\text { algorithm }\end{array}$} & \multirow{2}{*}{$\begin{array}{l}\text { Threshold } \\
\text { function }\end{array}$} & \multirow{2}{*}{$\begin{array}{l}\text { Number } \\
\text { of layers } \\
\text { and } \\
\text { neurons }\end{array}$} & \multirow[t]{2}{*}{$M S E$} & \multicolumn{2}{|l|}{ Train } & \multicolumn{2}{|l|}{ Test } \\
\hline & & & & & $R^{2}$ & $M A E$ & $R^{2}$ & $M A E$ \\
\hline FFBP & LM & $\begin{array}{l}\text { TAN-TAN- } \\
\text { PUR }\end{array}$ & $2-10-10-1$ & 0.00044 & 0.9993 & 0.0047 & 0.9994 & 0.0041 \\
\hline FFBP & BR & $\begin{array}{l}\text { TAN-LOG- } \\
\text { PUR }\end{array}$ & $2-15-10-1$ & 0.00099 & 0.9988 & 0.0089 & 0.9990 & 0.0076 \\
\hline CFBP & LM & $\begin{array}{l}\text { TAN-TAN- } \\
\text { PUR }\end{array}$ & $2-12-1$ & 0.00084 & 0.9991 & 0.0064 & 0.9992 & 0.0057 \\
\hline CFBP & BR & $\begin{array}{l}\text { TAN-TAN- } \\
\text { TAN }\end{array}$ & $2-8-8-1$ & 0.00102 & 0.9988 & 0.0093 & 0.9989 & 0.0082 \\
\hline
\end{tabular}

\subsubsection{Microwave dryer}

Table 6 presents the best networks with the highest $\mathrm{R}^{2}$ values and the lowest MAE and MSE values for prediction MR of apple slices in microwave dryer. The cascade forward back propagation (CFBP) structure, TAN- TAN- TAN threshold function, LM algorithm with 2-15-10-1 topology structure had 
the lowest MSE (0.00059), MAE (0.0045 for test and 0.0053 for train) values and the highest $R^{2}$ (0.9993 for test and 0.9991 train) values (Table 6).

Table 6. The best values of evaluation criteria for FFBF and CFBF networks in different conditions of the number of layers and threshold functions for MR in microwave dryer

\begin{tabular}{|c|c|c|c|c|c|c|c|c|}
\hline \multirow[t]{2}{*}{ Network } & \multirow{2}{*}{$\begin{array}{l}\text { Training } \\
\text { algorithm }\end{array}$} & \multirow{2}{*}{$\begin{array}{l}\text { Threshold } \\
\text { function }\end{array}$} & \multirow{2}{*}{$\begin{array}{l}\text { Number of } \\
\text { layers } \\
\text { and neurons }\end{array}$} & \multirow[t]{2}{*}{$M S E$} & \multirow{2}{*}{$\begin{array}{l}\text { Train } \\
R^{2}\end{array}$} & \multicolumn{3}{|c|}{ Test } \\
\hline & & & & & & $M A E$ & $R^{2}$ & $M A E$ \\
\hline FFBP & LM & TAN-PUR-LOG & $2-5-5-1$ & 0.00080 & 0.9988 & 0.0075 & 0.9989 & 0.0070 \\
\hline FFBP & $\mathrm{BR}$ & $\begin{array}{l}\text { TAN-LOG- } \\
\text { TAN }\end{array}$ & $2-10-1$ & 0.00064 & 0.9990 & 0.0059 & 0.9992 & 0.0051 \\
\hline CFBP & LM & $\begin{array}{l}\text { TAN-TAN- } \\
\text { TAN }\end{array}$ & $2-15-10-1$ & 0.00059 & 0.9991 & 0.0053 & 0.9993 & 0.0045 \\
\hline CFBP & $\mathrm{BR}$ & TAN-TAN-PUR & $2-8-8-1$ & 0.00095 & 0.9984 & 0.0094 & 0.9986 & 0.0088 \\
\hline
\end{tabular}

\section{Conclusion}

The effects of $\mathrm{CD}$ and $\mathrm{MD}$ at different air temperatures $\left(50,60\right.$ and $70^{\circ} \mathrm{C}$ ), and microwave powers (90, 180 , and $360 \mathrm{~W}$ ) on the drying characteristics of apple slice were evaluated in this study. The drying time of apple slice was the highest in MD drying as compared to another one. Midili et al. model was the most suitable model for prediction of apple MR. This model had the highest correlation coefficients $\left(R^{2}\right)$ and lowest chi-square $\left(\chi^{2}\right)$ and root mean square error ( $R M S E$ ) values. So, it can be able to describe the thin layer drying characteristics of samples at two dryers. The maximum $D_{\text {eff }}$ value of $8.21 \times 10^{-7} \mathrm{~m}^{2} / \mathrm{s}$ was obtained under the MD with power of $360 \mathrm{~W}$. The minimum SEC value $\left(52.03 \mathrm{MJ} / \mathrm{kg}\right.$ ) was obtained from microwave drying. The obtained $\mathrm{R}^{2}$ values using ANN for predication of MR at two different dryers (data test) were equal to 0.9993 and 0.9990 in CD and MD, respectively.

\section{References}

1. Aghbashlo, M., Kianmehr, M. H., \& Arabhosseini, A. Modeling of thin-layer drying of apple slices in a semi-industrial continuous band dryer. Int. J. Food Eng. 6(4), 1-6 (2010).

2. Antal, T., \& Kerekes, B. Investigation of Hot air-and infrared-assisted freeze-drying of apple. J. Food Process. Preserv. 40(2), 257-269 (2016).

3. Shalini, R., \& Gupta, D. Utilization of pomace from apple processing industries: a review. $J$. Food Sci. Technol. 47(4), 365-371 (2010).

4. Adam, K. L. Food Dehydration Options. US: National Sustainable Agriculture Information Service. Aeroglide Corporation, Cary, NC. 919-851- 2000 (2004).

5. Cheng, L.-S., Fang, S., \& Ruan, M.-L. Influence of blanching pretreatment on the drying characteristics of cherry tomato and mathematical modeling. Int. J. Food Eng. 11(2), 265-274 (2015).

6. Funebo, T., Ahrné, L. 1. a., Kidman, S., Langton, M., \& Skjöldebrand, C. Microwave heat treatment of apple before air dehydration-effects on physical properties and microstructure. $J$. Food Eng. 46(3), 173-182 (2000). 
7. Prothon, F., Ahrné, L. 1. M., Funebo, T., Kidman, S., Langton, M., \& Sjöholm, I. Effects of combined osmotic and microwave dehydration of apple on texture, microstructure and rehydration characteristics. LWT-Food Sci Technol. 34(2), 95-101 (2001).

8. Izli, N., \& Isik, E. Color and microstructure properties of tomatoes dried by microwave, convective, and microwave-convective methods. Int. J. Food Prop. 18(2), 241-249 (2015).

9. Seremet, L., Botez, E., Nistor, O.-V., Andronoiu, D. G., \& Mocanu, G.-D. Effect of different drying methods on moisture ratio and rehydration of pumpkin slices. Food Chem. 195, 104109 (2016).

10. Lüle, F., \& Koyuncu, T. Convective and microwave drying characteristics of sorbus fruits (Sorbus domestica L.). Procedia Soc Behav Sci 195, 2634-2643 (2015).

11. Das, C., Das, A., \& Golder, A. K. Optimality in microwave-assisted drying of Aloe Vera (Aloe barbadensis Miller) gel using Response Surface Methodology and Artificial Neural Network Modeling. J. Inst. Eng. India Ser. E. 97(2), 143-149. (2016).

12. Ramzi, M., Kashaninejad, M., Salehi, F., Mahoonak, A. R. S., \& Razavi, S. M. A. Modeling of rheological behavior of honey using genetic algorithm-artificial neural network and adaptive neuro-fuzzy inference system. Food Biosci. 9, 60-67 (2015).

13. Salehi, F., \& Razavi, S. M. Modeling of waste brine nanofiltration process using artificial neural network and adaptive neuro-fuzzy inference system. Desalin Water Treat. 57(31), 14369-14378 (2016).

14. Kamiński, W., Tomczak, E., \& Strumill, P. Neurocomputing approaches to modelling of drying process dynamics. Drying Techn. 16(6), 967-992 (1998).

15. Momenzadeh, L., Zomorodian, A., \& Mowla, D. Experimental and theoretical investigation of shelled corn drying in a microwave-assisted fluidized bed dryer using Artificial Neural Network. Food Bioprod Process. 89(1), 15-21 (2011).

16. Movagharnejad, K., \& Nikzad, M. Modeling of tomato drying using artificial neural network. Comput Electron Agric. 59(1-2), 78-85 (2007).

17. Nikbakht, A. M., Motevali, A., \& Minaei, S. Energy and exergy investigation of microwave assisted thin-layer drying of pomegranate arils using artificial neural networks and response surface methodology. J. Saudi Soc. Agric. Sci. 13(2), 81-91 (2014).

18. ASAE. Moisture measurement unground grain and seeds. In. (2007).

19. Ghanbarian, D., Dastjerdi, M. B., \& Torki-Harchegani, M. Mass transfer characteristics of bisporus mushroom (Agaricus bisporus) slices during convective hot air drying. Heat Mass Transfer. 52(5), 1081-1088 (2016).

20. Zarein, M., Samadi, S. H., \& Ghobadian, B. Investigation of microwave dryer effect on energy efficiency during drying of apple slices. J. Saudi Soc. Agric. Sci. 14(1), 41-47 (2015).

21. Aktaş, M., Khanlari, A., Amini, A., \& Şevik, S. Performance analysis of heat pump and infrared-heat pump drying of grated carrot using energy-exergy methodology. Energy Convers. and Manag. 132, 327-338 (2017).

22. Dinani, S. T., Hamdami, N., Shahedi, M., \& Havet, M. Mathematical modeling of hot air/electrohydrodynamic (EHD) drying kinetics of mushroom slices. Energy Convers. Manag. 86, 70-80 (2014).

23. Shi, Q., Zheng, Y., \& Zhao, Y. Mathematical modeling on thin-layer heat pump drying of yacon (Smallanthus sonchifolius) slices. Energy Convers. Manag. 71, 208-216 (2013).

24. Avhad, M., \& Marchetti, J. Mathematical modelling of the drying kinetics of Hass avocado seeds. Ind Crops Prod. 91, 76-87 (2016).

25. Blanco-Cano, L., Soria-Verdugo, A., Garcia-Gutierrez, L., \& Ruiz-Rivas, U. Modeling the thin-layer drying process of Granny Smith apples: Application in an indirect solar dryer. Appl. Therm. Eng. 108, 1086-1094 (2016).

26. Mghazli, S., Ouhammou, M., Hidar, N., Lahnine, L., Idlimam, A., \& Mahrouz, M. Drying characteristics and kinetics solar drying of Moroccan rosemary leaves. Renew. Energy 108, 303-310 (2017). 
27. Kaveh, M., \& Amiri Chayjan, R. Modeling thin-layer drying of turnip slices under semi-industrial continuous band dryer. J. Food Process. Preserv. 41(2), e12778 (2017).

28. Jiang, J., Dang, L., Tan, H., Pan, B., \& Wei, H. Thin layer drying kinetics of pre-gelatinized starch under microwave. Taiwan Inst Chem Eng. 72, 10-18 (2017).

29. Rabha, D., Muthukumar, P. \& Somayaji, C. Experimental investigation of thin layer drying kinetics of ghost chilli pepper (Capsicum Chinense Jacq.) dried in a forced convection solar tunnel dryer. Renew. Energy 105, 583-589 (2017).

30. Koukouch, A., Idlimam, A., Asbik, M., Sarh, B., Izrar, B., Bostyn, S., Amine, A. Experimental determination of the effective moisture diffusivity and activation energy during convective solar drying of olive pomace waste. Renew. Energy 101, 565-574 (2017).

31. Muliterno, M. M., Rodrigues, D., de Lima, F. S., Ida, E. I., \& Kurozawa, L. E. Conversion/degradation of isoflavones and color alterations during the drying of okara. $L W T$ Food Sci Technol. 75, 512-519 (2017).

32. Zhu, A., \& Shen, X. The model and mass transfer characteristics of convection drying of peach slices. Int. J. Heat Mass Transfer. 72, 345-351 (2014).

33. Aral, S., \& Beşe, A. V. Convective drying of hawthorn fruit (Crataegus spp.): effect of experimental parameters on drying kinetics, color, shrinkage, and rehydration capacity. Food Chem. 210, 577-584 (2016).

34. Minaei, S., Motevali, A., Ahmadi, E., \& Azizi, M. H. Mathematical models of drying pomegranate arils in vacuum and microwave dryers. J. Agric. Sci. Technol. 14(2), 311-325 (2012).

35. Darvishi, H., Khoshtaghaza, M. H., Najafi, G., \& F. N. Mathematical modeling of green pepper drying in microwave-convective dryer. J. Agric. Sci. Technol. 15, 457-465 (2013).

36. Chayjan, R. A., Kaveh, M., \& Khayati, S. Modeling some thermal and physical characteristics of terebinth fruit under semi industrial continuous drying. J. Food Meas. Charact. 11(1), 1223 (2017a).

37. Khoshtaghaza, M. H., Darvishi, H., \& Minaei, S. Effects of microwave-fluidized bed drying on quality, energy consumption and drying kinetics of soybean kernels. J. Food Sci. Technol. 52(8), 4749-4760 (2015).

38. Łechtańska, J., Szadzińska, J., \& Kowalski, S. Microwave-and infrared-assisted convective drying of green pepper: Quality and energy considerations. Chem Eng Process.: Process Intensification 98, 155-164 (2015).

39. Pu, Y. Y., \& Sun, D. W. Combined hot-air and microwave-vacuum drying for improving drying uniformity of mango slices based on hyperspectral imaging visualisation of moisture content distribution. Biosyst Eng. 156, 108-119 (2017).

40. Hasanipanah, M., Amnieh, H. B., Arab, H., \& Zamzam, M. S. Feasibility of PSO-ANFIS model to estimate rock fragmentation produced by mine blasting. Neural. Comput. Appl. 30(4), 1015-1024 (2018).

41. Wang, Z., Sun, J., Chen, F., Liao, X., \& Hu, X. Mathematical modelling on thin layer microwave drying of apple pomace with and without hot air pre-drying. J. Food Eng. 80(2), 536-544 (2007).

42. Beigi, M. Hot air drying of apple slices: dehydration characteristics and quality assessment. Heat Mass Transfer. 52(8), 1435-1442 (2016).

43. Kaleta, A., Górnicki, K., Winiczenko, R., \& Chojnacka, A. Evaluation of drying models of apple (var. Ligol) dried in a fluidized bed dryer. Energy Convers. Manag. 67, 179-185 (2013).

44. Kara, C., \& Doymaz, I. Effective moisture diffusivity determination and mathematical modelling of drying curves of apple pomace. Heat Mass Transfer. 51(7), 983-989 (2015).

45. Samadi, S. H., Ghobadian, B., Najafi, G., Motevali, A., \& Faal, S. Drying of apple slices in combined heat and power (CHP) dryer: comparison of mathematical models and neural networks. Chem Prod Process Model 8(1), 41-52 (2013). 
46. Süfer, Ö., Sezer, S., \& Demir, H. Thin layer mathematical modeling of convective, vacuum and microwave drying of intact and brined onion slices. J. Food Process. Preserv. 41, e13239 (2017).

47. Kantrong, H., Tansakul, A., \& Mittal, G. S. Drying characteristics and quality of shiitake mushroom undergoing microwave-vacuum drying and microwave-vacuum combined with infrared drying. J. Food Sci. Technol. 51(12), 3594-3608 (2014).

48. Horuz, E., \& Maskan, M. Hot air and microwave drying of pomegranate (Punica granatum L.) arils. J. Food Sci. Technol. 52(1), 285-293 (2015).

49. Md Salim, N. S., Gariépy, Y., \& Raghavan, V. Hot air drying and microwave-assisted hot air drying of broccoli stalk slices (Brassica oleracea L. var. Italica). J. Food Process. Preserv. 41(3), e12905 (2017).

50. Chayjan, R. A., Kaveh, M., Dibagar, N., \& Nejad, M. Z. Optimization of pistachio nut drying in a fluidized bed dryer with microwave pretreatment applying response surface methodology. Chem Prod Process Model 12(3) (2017).

51. Torki-Harchegani, M., Ghasemi-Varnamkhasti, M., Ghanbarian, D., Sadeghi, M., \& Tohidi, M. Dehydration characteristics and mathematical modelling of lemon slices drying undergoing oven treatment. Heat Mass Transfer. 52(2), 281-289 (2016).

52. Darvishi, H., Zarein, M., Minaei, S., \& Khafajeh, H. Exergy and energy analysis, drying kinetics and mathematical modeling of white mulberry drying process. Int. J. Food Eng. 10(2), 269-280 (2014).

53. Ganesapillai, M., Murugan, P., \& Singh, A. Experimental analysis of microwave drying kinetics and characterization of ginger rhizomes. J. Food Process. Preserv. 36(5), 401-411 (2012).

54. Doymaz, İ., Demir, H., \& Yildirim, A. Drying of quince slices: effect of pretreatments on drying and rehydration characteristics. Chem Eng Commun. 202(10), 1271-1279 (2015).

55. Doymaz, İ., \& Sahin, M. Effect of temperature and pre-treatment on drying and rehydration characteristics of broccoli slices. J. Food Meas. Charact. 10(2), 364-373 (2016).

56. Bal, L. M., Kar, A., Satya, S., \& Naik, S. N. Drying kinetics and effective moisture diffusivity of bamboo shoot slices undergoing microwave drying. Int. J. Food Sci. Technol. 45(11), 23212328 (2010).

57. Darvishi, H., Zarein, M., \& Farhudi, Z. Energetic and exergetic performance analysis and modeling of drying kinetics of kiwi slices. J. Food Sci. Technol. 53(5), 2317-2333 (2016).

58. Khanali, M., Banisharif, A., \& Rafiee, S. Modeling of moisture diffusivity, activation energy and energy consumption in fluidized bed drying of rough rice. Heat Mass Transfer. 52(11), 2541-2549 (2016).

59. Tripathy, P., Abhishek, S., \& Bhadoria, P. Determination of convective heat transfer coefficient and specific energy consumption of potato using an ingenious self-tracking solar dryer. J. Food Meas. Charact. 8(1), 36-45 (2014).

60. Celen, S., \& Kahveci, K. Microwave drying behaviour of tomato slices. Czech J. Food Sci. 31(2). 132-138 (2013) .

61. Fisk, C. L., Silver, A. M., Strik, B. C., \& Zhao, Y. Postharvest quality of hardy kiwifruit (Actinidia arguta 'Ananasnaya') associated with packaging and storage conditions. Postharvest Biol. Technol. 47(3), 338-345 (2008).

62. Yosefian, S., Razdari, A. M., Seihoon, M., \& Kyani, H. Determination of optimal conditions using response surface method and comparision of naural network and regression method of drying gamma irradiated potato. Food Sci. Technol. 13(59) 85-96 (2017).

63. Tavakolipour, H., Mokhtarian, M., \& Kalbasi-Ashtari, A. Intelligent monitoring of zucchini drying process based on fuzzy expert engine and ANN. J. Food Process Eng. 37(5), 474-481 (2014). 


\section{Author contributions}

Methodology, V.RS., R.A. and M.K. Formal analysis, V.RS., M.K. and M.S. Investigation, V.RS., R.A. and M.K . Experiment conduction, V.RS., R.A. and M.K. Statistical Analysis, V.RS., R.A., M.K. and W.T. Writing original draft preparation, V.RS., R.A., M.K. and M.S. All authors reviewed the manuscript.

\section{Competing interests}

The authors declare no competing interests. 
Figures

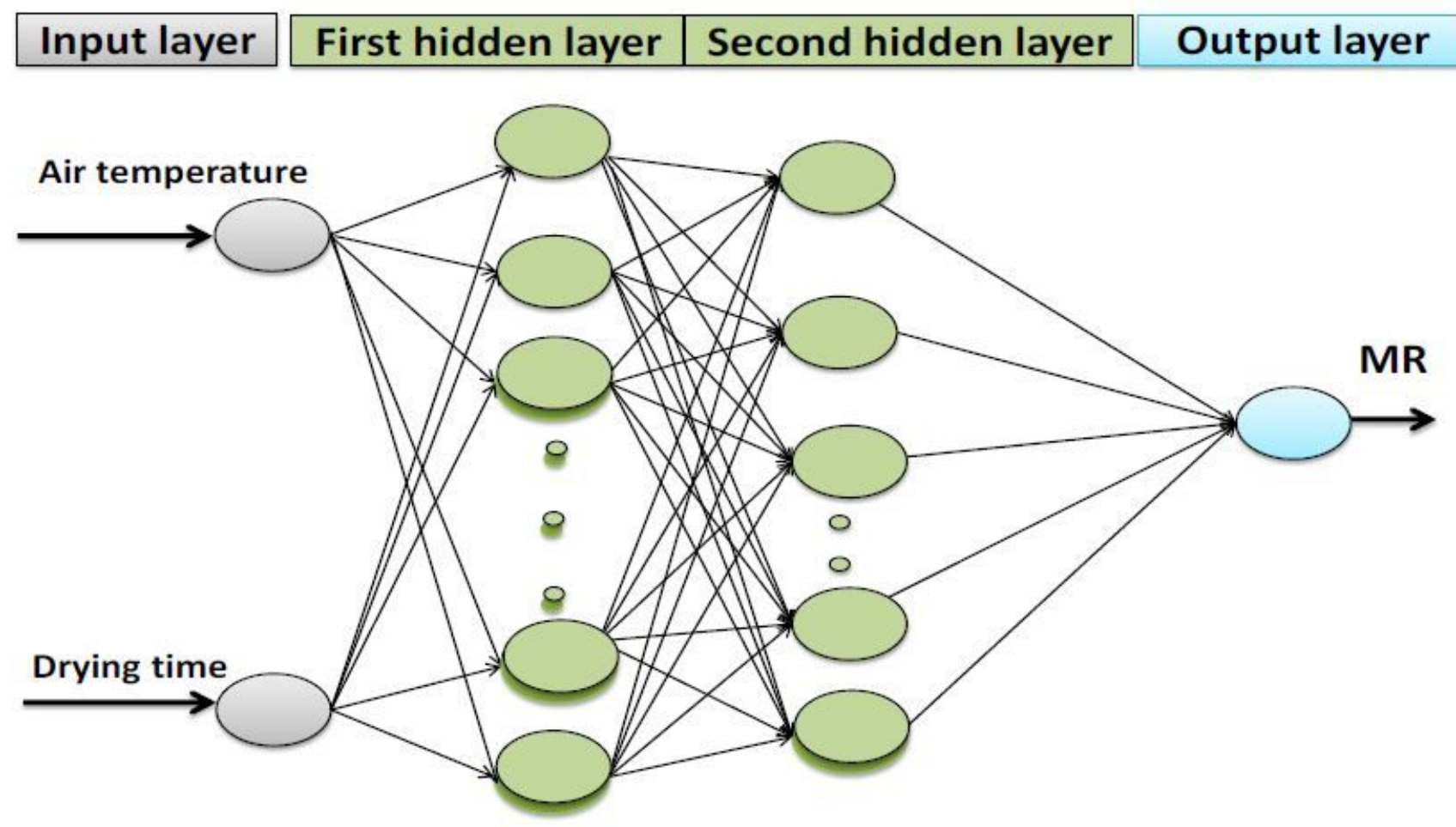

Figure 1

Four-layer ANN inputs and output structure used in this study

a)

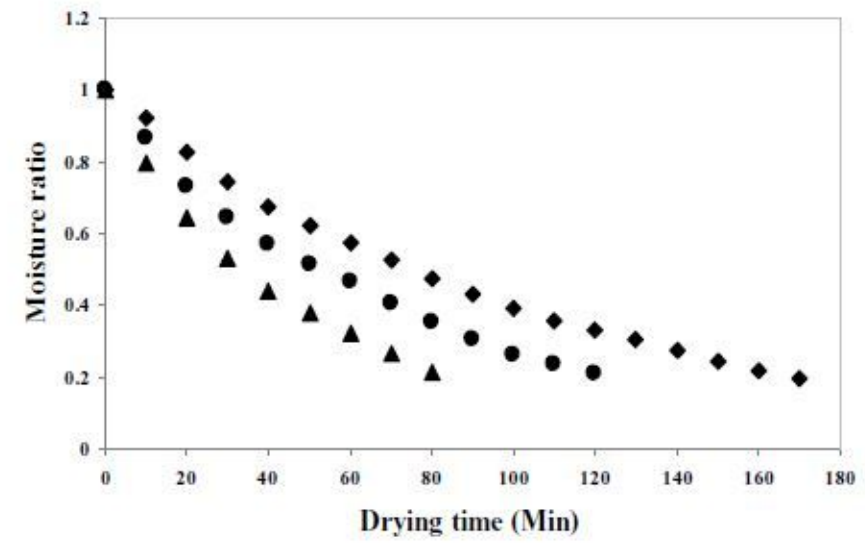

b)

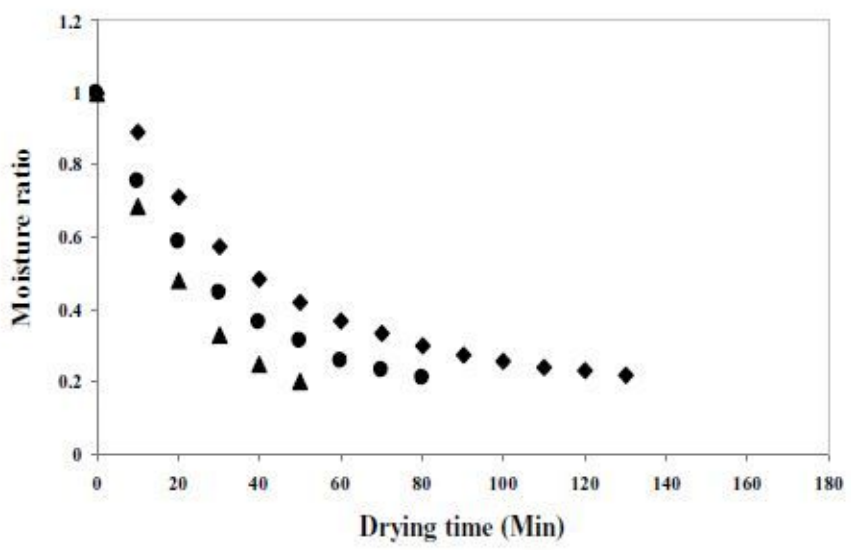

Figure 2

"See the Supplemental Files section for the complete figure caption". 
a)

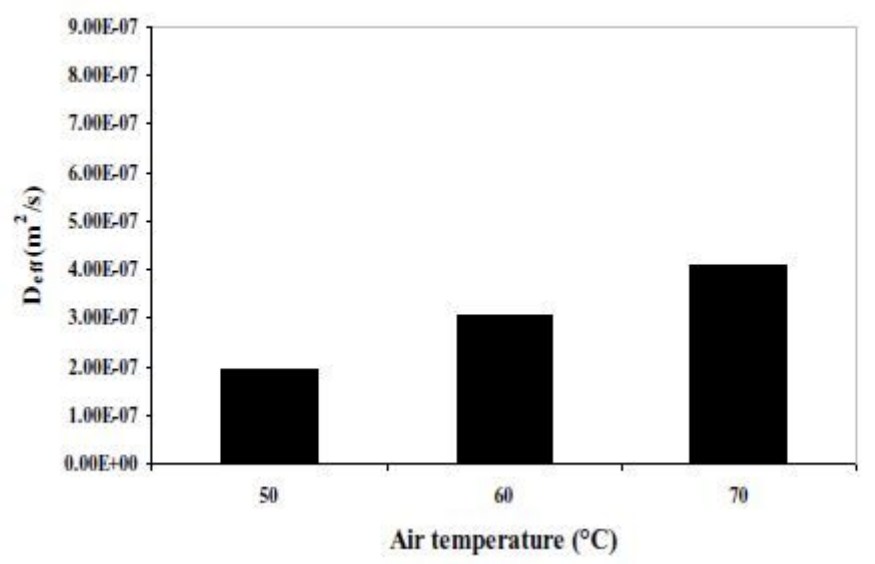

b)

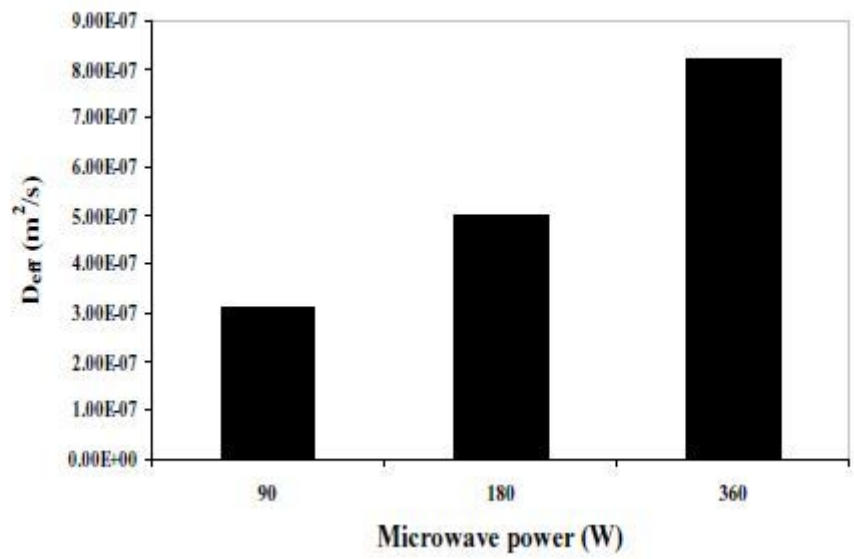

Figure 3

Effective moisture diffusivity ( Deff ) for drying of apple slice in different: a) air temperature, b) microwave power

a)

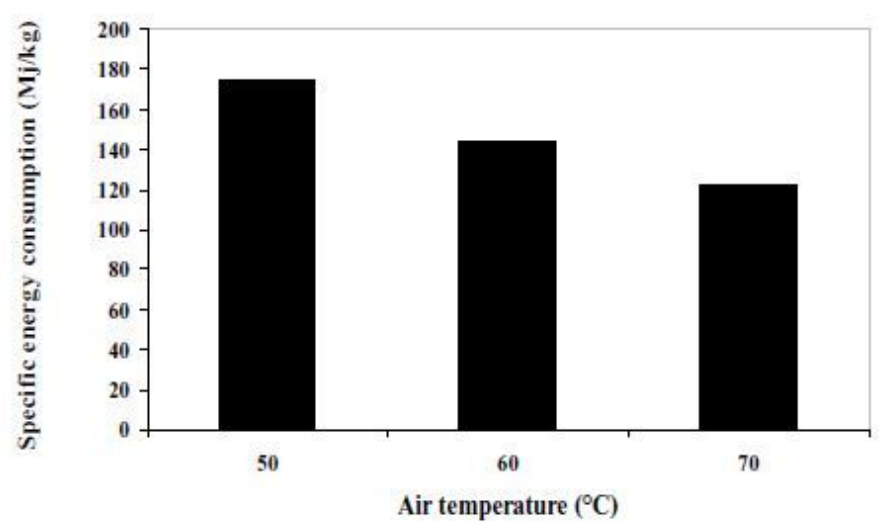

b)

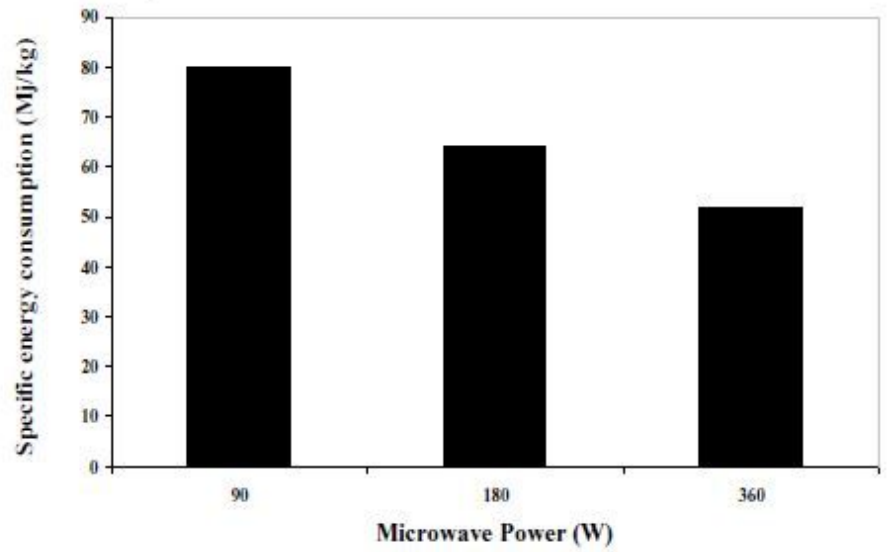

Figure 4

Variations of specific energy consumption for drying process of apple slice in different: a) air temperature, b) microwave power 

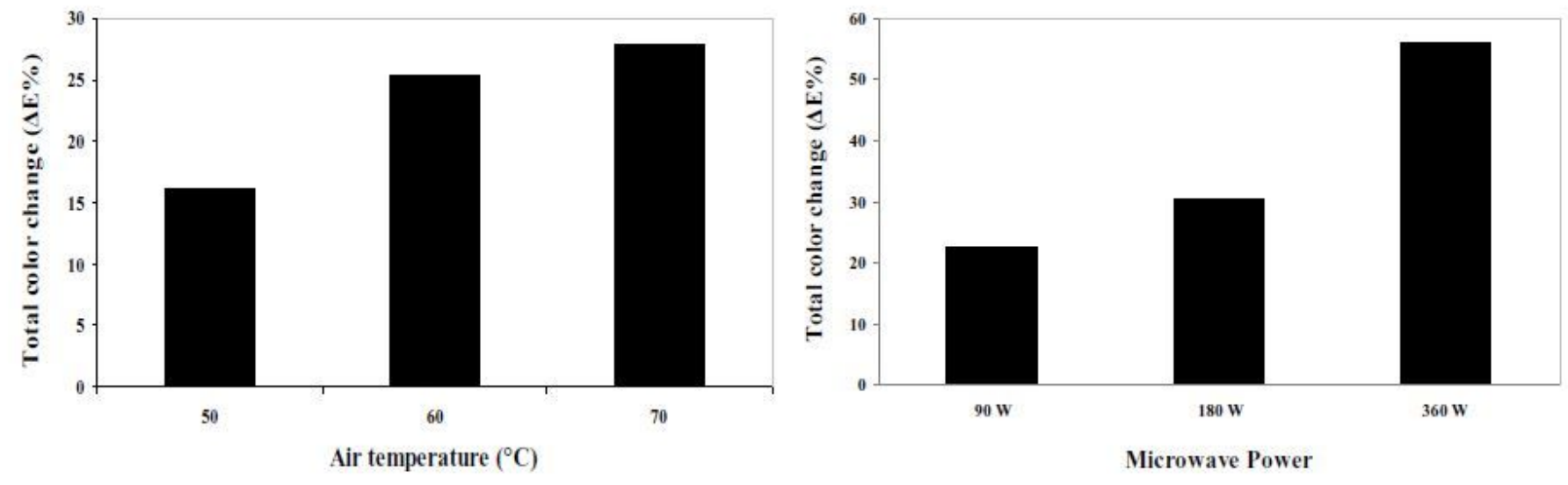

Figure 5

Color change values of apple slices in different a) air temperature, b) microwave power

\section{Supplementary Files}

This is a list of supplementary files associated with this preprint. Click to download.

- FigureCaption.docx 